\title{
The Obex Is Not Synonymous with the Upper End of the Central Canal
}

Thomas H. Milhorat, MD, Department of Neurosurgery, State University of New York, Health Science Center at Brooklyn, 450 Clarkson Avenue, PO Box 1189, Brooklyn, NY 11203-2098 (USA)

\section{Dear Sir,}

The recently published paper, Obex/Nu-cleus gracilis Position: Its Role as a Marker for the Cervicomedullary Junction [1], perpetuates the misconception that the obex is synonymous with the opening at the upper end of the central canal. To be precise, the obex is a thin band of neural tissue which extends transversely between the laterally consolidated nuclei of the area postrema [2]. Viewed sagittally (fig. 1), the obex forms the dorsal roof of the central canal opening or aperture, and its tip defines the inferior margin of the foramen of Magendie.

In the paper by Quisling et al. [1], figures 2 and 3 are mislabelled: the structure labelled 'obex' is the aperture of the central canal; the structure labelled 'nucleus gracilis' is the obex (the nucleus gracilis at this level cannot be imaged in the midsagittal plane because it diverges from the midline and lies lateral to the obex). The aperture of the central canal and the tip of the obex are usually well seen on conventional midsagittal MR images, and are useful landmarks in describing hindbrain malformations [3].

\section{' " $5 / 8^{3 / 8} / 8$}

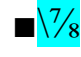

1

\section{CCA}

FM

". I’.

References

Quisling RG, Quisling SG, Mickle JP: Obex/ nucleus gracilis position: Its role as a marker for the cervicomedullary junction. Pediatr Neurosurg 1993;19:143150 .

Wilson JT: On the anatomy of the calamus region in the lumen bulb: With an account of a hitherto undescribed 'nucleus postremus'. J AnatPhysiol 19O6;71:423-428. Milhorat TH, Miller JI, Johnson WD, et al: Anatomical basis of syringomyelia occurring with hindbrain lesions. Neurosurgery 1993;32: $748-754$.

Fig. 1. Midsagittal section through upper end of central canal in 32O-gram fetus. $\mathrm{O}=$ Obex; $\mathrm{CCA}=$ central canal aperture; $\mathrm{FM}=$ foramen of Magendie. $\times 40$. With permission from Neurosurgery [3].

C) 1994 [S.KargerAG, Basel

1. 1016-2291/94/0211-0112

$\$ 8.00 / 0$ 